\title{
The use of SI units in reporting results obtained in hospital laboratories
}

\author{
D. N. BARON, P. M. G. BROUGHTON ${ }^{1}$, M. COHEN, T. S. LANSLEY, \\ S. M. LEWIS, AND N. K. SHINTON
}

From the Department of Chemical Pathology, Royal Free Hospital, London, the Department of Chemical Pathology, University of Leeds, the Department of Medical Physics, the London Hospital, the Department of Pathology, East Ham Memorial Hospital, London, the Department of Haematology, Royal Postgraduate Medical School, London, and the Department of Pathology, Coventry and Warwickshire Hospital

This paper outlines some recommendations for the use of SI units in reporting the results of investigations made in hospital laboratories. It is based on a report prepared by a working party of representatives of a number of organizations ${ }^{2}$ which was approved in 1973 by the councils or committees of these organizations. A summary of the main recommendations has already been published (Baron, 1973).

In recommending the introduction of SI units for the reporting of results obtained in hospital laboratories in the UK, the working party are following the decisions of the relevant international associations (IUPAC-IFCC, 1972a and b; ICSH-IFCCWAPS, 1972). Laboratories all over the world are, or will be, adopting SI units (Young, 1974). During recent years users of laboratory results (physicians, nurses, pharmacists, etc) have made the change from the Imperial system of weights and measures to the metric system. In most hospitals the first stage of SI will have already been introduced, namely, standardization of symbols for units, and replacement of the equivalent by the mole for monovalent ions where no change in number results (Royal College of Pathologists Working Party, 1970).

The working party considered that a start should now be made in bringing into general use in medicine in Britain the second and final stage of SI units. This will introduce some relatively unfamiliar units, such as the pascal $(\mathrm{Pa})$ for pressure and the joule $(\mathrm{J})$ for energy. The great advantage of these units is that they are the same for all branches of science, and in

\footnotetext{
${ }^{1}$ Correspondence should be addressed to Mr P. M. G. Broughton, University Department of Chemical Pathology, General Infirmary, Leeds LS1 3EX.

2Association of Clinical Biochemists, Association of Clinical Pathologists, Biological Engineering Society, British Society for Haematology, Hospital Physicists' Association, Institute of Medical Laboratory Technology, Royal College of Pathologists, Section of Measurement in Medicine of the Royal Society of Medicine.

Received for publication 6 May 1974.
}

adopting them medicine will ensure that it does not in become isolated with such units as $\mathrm{mmHg}$ and Calorie (whose replacement has been recommended 웅 by the British National Committee for Nutritional Sciences, 1972). The other major recommendation is the great importance given to the mole (and its submultiples such as the millimole). For all sub- $\vec{\theta}$ stances of known molecular weight (except haemo- + globin) concentration should be expressed in terms of numbers of molecular units ('amount of substance') per unit volume (normally the litre) as this corresponds to the actual biological activity, whereas the former means of expression, mass per volume, does not. The advantages of expressing concentration measurements in this way have been reviewed by several authors (Astrup, 1970; IUPAC-IFCC, 1972a; Owen, Edwards, and Collier, 1970; Young, 1974).

These recommendations are made to codify the changes necessary for those working in hospital 응 laboratories, and to enable users to take the neces- $\frac{0}{0}$ sary educational and practical steps necessary for full implementation.

\section{Reasons for Using SI}

The units currently used for expressing the results of measurements made in medicine have developed $\mathrm{N}$ empirically and are now so diverse that there is a ${ }^{\mathrm{G}}$ danger that results may be misunderstood by those $N$ not familiar with the particular scale of units used. N This danger can be averted only by the universal 0 adoption of a common system of units in all branches of science and medicine. The system recommended $\frac{}{\Phi}$ is the International System of Units (SI). It is based $\stackrel{\oplus}{+}$ on the metric system and is designed to: $(a)$ provide 0 a coherent system of units, ie, a system in which the $\bar{O}$ product or quotient of any two unit quantities is the unit of the resultant quantity, without introducing $\mathbb{D}$ any numerical factor; for example, unit area $=$ unit $\sigma$ length $\times$ unit length, unit velocity $=$ unit length $/$ 590 
unit time; $(b)$ ensure that the presentation of quantities and units is uniform in concept and style; (c) minimize the number of multiples and submultiples in common use.

SI units are being used throughout pure science and are taught in schools and universities. They are being applied in medical and scientific journals (Royal Society of Medicine, 1972) and are being adopted in many countries for reporting laboratory results and other data in medicine. The recommendations given in this paper, which relate to their use in hospitals in Britain, are in conformity with all the international recommendations on this subject.

\section{Outline of SI}

SI units are based on the seven base units shown in table I.

Derived SI units are obtained by appropriate combination of these base units, thus allowing any physical quantity to be expressed in terms of SI units. For example, the SI unit of velocity is metre per second $\left(\mathrm{m} / \mathrm{s}\right.$ or $\left.\mathrm{m} \cdot \mathrm{s}^{-1}\right)$. Some derived SI units have special names and symbols, the more importa nt ones being as shown in table II.

It should be noted that the coherent SI unit of volume is the cubic metre. However, the litre is also recognized as a unit of volume and is exactly equal to one cubic decimetre, ie, 1000 litre = 1 cubic metre. Because of its convenience, the litre is here recommended as the unit of volume in laboratory work. Concentrations of solutions are therefore expressed with the litre (not the cubic metre) in the denominator:

Mass concentration $\quad \ldots \quad \ldots \quad \ldots \quad \ldots k$ kg/l Amount of substance ('molar') concentration. . mol/l

Decimal multiples and sub-multiples of SI units are formed with the prefixes shown in table III.

\begin{tabular}{lll}
\hline Physical Quantity & Name of SI Unit & Symbol for SI Unit \\
\hline Length & metre & $\mathrm{m}$ \\
Mass & kilogram & $\mathrm{kg}$ \\
Time & second & $\mathrm{s}$ \\
Electric current & ampere & $\mathrm{A}$ \\
Thermodynamic temperature & kelvin & $\mathrm{K}$ \\
Luminous intensity & candela & $\mathrm{cd}$ \\
Amount of substance & mole & $\mathrm{mol}$ \\
\hline
\end{tabular}

Table I Names and symbols for basic SI units

\begin{tabular}{|c|c|c|c|c|}
\hline Quantity & Name of SI Unit & Symbol & $\begin{array}{l}\text { Expre } \\
\text { Derive }\end{array}$ & $\begin{array}{l}\text { ssion in Terms of SI Base Units or } \\
\text { ed Units }\end{array}$ \\
\hline $\begin{array}{l}\text { Frequency } \\
\text { Force } \\
\text { Work, energy, quantity of heat } \\
\text { Power } \\
\text { Quantity of electricity } \\
\text { Electric potential, potential difference, tension, } \\
\text { electromotive force } \\
\text { Electric capacitance } \\
\text { Electric resistance } \\
\text { Flux of magnetic induction, magnetic flux } \\
\text { Magnetic flux density, magnetic induction } \\
\text { Inductance } \\
\text { Pressure }\end{array}$ & $\begin{array}{l}\text { hertz } \\
\text { newton } \\
\text { joule } \\
\text { watt } \\
\text { coulomb } \\
\text { volt } \\
\text { farad } \\
\text { ohm } \\
\text { weber } \\
\text { tesla } \\
\text { henry } \\
\text { pascal }\end{array}$ & $\begin{array}{l}\text { Hz } \\
\text { N } \\
\text { J } \\
\text { W } \\
\text { C } \\
\text { V } \\
\text { F } \\
\Omega \\
\text { Wb } \\
\text { T } \\
\text { H } \\
\text { Pa }\end{array}$ & $\begin{array}{ll}1 & \mathrm{~Hz} \\
1 & \mathrm{~N} \\
1 & \mathrm{~J} \\
1 & \mathrm{~W} \\
1 \mathrm{C} \\
1 \mathrm{~V} \\
1 \mathrm{~F} \\
1 \mathrm{\Omega} \\
1 \mathrm{~Wb} \\
1 \mathrm{~T} \\
1 \mathrm{H} \\
1 \mathrm{~Pa}\end{array}$ & $\begin{array}{l}=1 / \mathrm{s} \\
=1 \mathrm{~kg} \cdot \mathrm{m} / \mathrm{s}^{2} \\
=1 \mathrm{~N} \cdot \mathrm{m} \\
=1 \mathrm{~J} / \mathrm{s} \\
=1 \mathrm{~A} \cdot \mathrm{s} \\
=1 \mathrm{~W} / \mathbf{A} \\
=1 \mathrm{~A} \cdot \mathrm{s} / \mathrm{V} \\
=1 \mathrm{~V} / \mathbf{A} \\
=1 \mathrm{~V} \cdot \mathbf{s} \\
=1 \mathrm{~Wb} / \mathrm{m}^{2} \\
=1 \mathrm{~V} \cdot \mathrm{s} / \mathbf{A} \\
=1 \mathrm{~N} / \mathrm{m}^{2} \\
=1 \mathrm{~kg} / \mathrm{m} \cdot \mathrm{s}^{2}\end{array}$ \\
\hline
\end{tabular}

Table II Special names and symbols for derived SI units

\begin{tabular}{|c|c|c|c|c|c|}
\hline Factor & Name & Symbol & Factor & Name & Symbol \\
\hline & & & $\begin{array}{l}10^{-18} \\
10^{-15}\end{array}$ & $\begin{array}{l}\text { atto- } \\
\text { femto- }\end{array}$ & a \\
\hline $10^{12}$ & tera- & $\mathbf{T}$ & $10^{-12}$ & pico- & p \\
\hline $10^{\circ}$ & giga- & G & $10^{-9}$ & nano- & n \\
\hline $10^{\circ}$ & mega- & $\mathbf{M}$ & $10^{-}$ & micro- & $\mu$ \\
\hline $10^{3}$ & kilo- & $\mathbf{k}$ & $10^{-3}$ & milli- & $\mathrm{m}$ \\
\hline $\begin{array}{l}10^{2} \\
10^{1}\end{array}$ & $\begin{array}{l}\text { hecto- } \\
\text { deca- }\end{array}$ & $\begin{array}{l}\text { h } \\
\text { da }\end{array}$ & $\begin{array}{l}10^{-2} \\
10^{-1}\end{array}$ & $\begin{array}{l}\text { centi- } \\
\text { deci- }\end{array}$ & $\begin{array}{l}\text { c } \\
\text { d }\end{array}$ \\
\hline
\end{tabular}

Table III Prefixes for SI units 
Rules for Using Units (British Standards Institution, 1972)

1 The use of prefixes representing 10 raised to a power which is a multiple of 3 is especially recommended. The most widely used prefixes are kilo, milli, and micro. Typewriters should be fitted with the symbol ' $\mu$ ' (micro) to avoid ambiguity in the use of small ' $u$ '. The symbol for a prefix acts as convenient shorthand: $0.000001 \mathrm{~g}=10^{-6} \mathrm{~g}=1 \mu \mathrm{g}$.

2 The combination of prefix and symbol is regarded as one new symbol.

$$
\begin{aligned}
& \mu \mathrm{l}^{-1} \text { means }\left(10^{-6}\right)^{-1} \text { not } 10^{-6} \mathrm{1}^{-1} \\
& \mathrm{~mm}^{3} \text { means }\left(10^{-3} \mathrm{~m}\right)^{3} \text { or } 10^{-9} \mathrm{~m}^{3} \text { not } 10^{-3} \mathrm{~m}^{3}
\end{aligned}
$$

3 Compound prefixes are to be avoided and only one prefix should be used in forming decimal multiples or submultiples: eg, $10^{-9} \mathrm{~g}$ is $1 \mathrm{ng}$ not $1 \mathrm{~m} \mu \mathrm{g}$.

A consequence of this rule is that in derived units the prefix should be attached to one unit only, preferably in the numerator; the kilogram is an exception, as $\mathbf{~ k g}$ is the fundamental unit.

4 Great care should be taken to avoid ambiguity, especially when using a prefix symbol which is identical with the symbol for a unit, eg, Newton metre is $\mathrm{N} \cdot \mathrm{m}$ not $\mathrm{mN}$ which means $10^{-3} \mathrm{~N}$.

No space should be left between the symbol for a prefix and its unit, whereas a space should be left between symbols in derived units, eg, 'ms' indicates millisecond but ' $\mathrm{m}$ s' indicates metres $\times$ second. For clarity a point above the line should be used, eg, $\mathrm{m} \cdot \mathrm{s} ; \mathrm{N} \cdot \mathrm{m}$. Whenever ambiguity could arise it is better not to abbreviate, eg, the symbol for year is ' $a$ ', but in Britain the word is better written in full. If any confusion could arise between the symbol for litre (l) and the figure 1 , the word litre should be written in full.

5 The symbol for a unit is unaltered in the plural and should not be followed by a full stop except at the end of the sentence, eg, $5 \mathrm{~cm}$, not $5 \mathrm{~cm}$. or $5 \mathrm{cms}$.

6 The solidus $(/)$ or word 'per' should only be used once in each unit. Where necessary the negative index may be used, eg, $\mathrm{ml} / \mathrm{min}$ or $\mathrm{ml} \mathrm{min}^{-1}$ not $\mathrm{ml} / \mathrm{min} / \mathrm{m}^{2}$ which could mean $(\mathrm{ml} / \mathrm{min}) / \mathrm{m}^{2}$ or $\mathrm{ml} /\left(\mathrm{min} / \mathrm{m}^{2}\right)$ and should be written as $\mathrm{ml} \cdot \mathrm{min}^{-1} \cdot \mathrm{m}^{-2}$.

7 The decimal sign between digits is indicated by a full stop in typing. No commas are used to divide large numbers into groups of three, but a half-space (whole space in typing) is left after every third digit. If the numerical value of the number is less than unity, a zero should precede the decimal sign: thus $0 \cdot 123456$ not $\cdot 123,456$.

8 When expressing a quantity by a numerical value and a unit, it is in most applications advisable to use a multiple or submultiple which gives a simple whole number between 1 and 999: eg, $10^{-5} \mathrm{~g}$ is best re- corded as $10 \mu \mathrm{g}$ and not $0.01 \mathrm{mg}$. This ruling cannot be consistently applied when in the same context numerical values expressed in the same unit extend over a considerable range.

9 Some decimal fractions and multiples of SI units have special names, eg, ångstrom, micron, dyne, erg. These names are not part of the SI system and although they may continue to be used for some time, they should be progressively abandoned as being unnecessary.

Although SI units are preferred, it will not be practical to limit usage to these. Any other unit and symbol may be used provided that it is defined. It is, however, important that symbols should not be ambiguous or be difficult to print. Symbols for SI units were chosen to be simple, systematic, easy to remember, and to use the minimum number of letters, and appropriate combinations should cover most eventualities. Arbitrary units may be invented for a particular purpose but must be defined and great care taken in the choice of symbols: eg, 'mouse units' are best written as such instead of 'mu' which could mean milliunits.

\section{Application to Laboratory Reports}

In principle a report of a measurement should always include information on (1) the system, (2) the component, (3) the kind of quantity, (4) the numerical value, and (5) the unit. Thus, as an example, plasma cholesterol can be reported as:

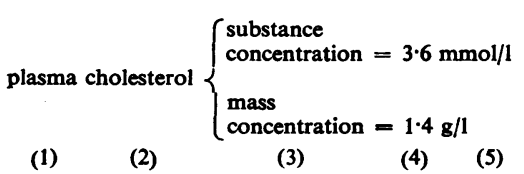

To report this result as 'cholesterol $=1.4$ ' is ambiguous and could lead to misinterpretation.

Particular care should be taken to ensure that the name of the component is unambiguous (IUPACIFCC, 1972b). Thus 'plasma bilirubin' could refer to unconjugated (indirect-reacting) bilirubin, whereas $\mathrm{O}$ it is usually intended to mean total bilirubins, ie, conjugated plus unconjugated. For acids and bases it is recommended that the designation of the maximally ionized form is used in naming the component. Thus for measurements in, say, plasma, the terms lactate, urate, pyruvate, and oxalate are preferred to lactic acid, uric acid, pyruvic acid, and oxalic acid. The term plasma ammonium includes both the ammonium ions and free ammonia present; ascorbate includes both ascorbate ion and free ascorbic acid. Examples of the recommended nomenclature are given in the Appendix. 


\section{CONCENTRATION}

The SI system includes two different types of unit of concentration: mass concentration $(\mathrm{g} / \mathrm{l}, \mathrm{mg} / \mathrm{l}$, $\mu \mathrm{g} / \mathrm{l}$, etc) and amount of substance ('molar') concentration (mol/l, $\mathrm{mmol} / \mathrm{l}, \mu \mathrm{mol} / \mathrm{l}$, etc). A choice must be made between the two when reporting all measurements of concentration.

For substances of defined chemical composition it is recommended that amount of substance concentration should be used. It may be applied to any defined particle, such as an ion, atom, molecule, or radical, but the nature of the particle must be self evident in the report. Equivalent concentration $(\mathrm{mEq} / \mathrm{l})$ is commonly used for reporting the results of monovalent electrolyte measurements (sodium, potassium, chloride, and bicarbonate). It is, however, not part of the SI system and should be replaced by molar concentration (in these examples mmol/l). For these four measurements and other monovalent ions the numerical value will not change.

Mass concentration is recommended for all protein measurements and for substances which do not have a sufficiently well defined composition. Mass concentration is also recommended for expressing the results of plasma vitamin $B_{12}$ and folate measurements, as the molecular weight of the biologically active compound is uncertain. However, the SI unit of mass concentration is expressed in terms of the litre, eg, g/l, mg/l, etc, whereas at present many measurements of mass concentration use $100 \mathrm{ml}$ as the unit of volume $(\mathrm{g} / 100 \mathrm{ml}, \mathrm{mg} / 100 \mathrm{ml}$, etc). For these the numerical value will therefore change by a factor of 10 .

An exception is made in the case of haemoglobin (ICSH-IFCC-WAPS, 1972). Because of the uncertainty concerning the exact elementary entity of haemoglobin which should be used for calculation of molar concentration, it is now agreed internationally that for the time being haemoglobin concentration in blood should be expressed as mass concentration, either $\mathrm{g} / \mathrm{l}$ or $\mathrm{g} / \mathrm{dl}$ (where $\mathrm{dl}$ is the SI symbol for $100 \mathrm{ml}$ ). Both these forms of expression are acceptable within the SI system. However, most laboratories in Britain currently report their haemoglobin results as $\mathrm{g} / \mathrm{dl}(\mathrm{g} / 100 \mathrm{ml})$ and there does not appear to be any advantage in their changing to $\mathrm{g} / \mathrm{l}$ when a further change to molar concentration might be recommended in the future.

Currently measurements of human serum immunoglobulins are frequently expressed as mass concentration (usually $\mathrm{mg} / 100 \mathrm{ml}$ ). Since a pure reference material is not available, Anderson et al (1972) have recommended that serum concentrations of IgG, IgA, and IgM should be expressed in terms of International Units, based on international reference preparations.
PRESSURE

The SI unit of pressure is the pascal (symbol Pa), which will eventually replace the very wide range of units of pressure which are at present used by different specialities. However, in this paper, the only recommendation made is that blood gas measurements should be given in the SI unit $(\mathrm{kPa})$ instead of mmHg: $1 \mathrm{mmHg}=133.32 \mathrm{~Pa}, 1 \mathrm{kPa}=7.5006$ $\mathrm{mmHg}$.

\section{TIME}

The SI unit for time is the second. In general, prefixes for SI multiples should not be used but time should continue to be expressed in seconds (s), minutes (min), hours (h); submultiple prefixes should be used only with the second, ie, as ms, $\mu \mathrm{s}$, ns, and not with minute or hour. Instead the quantity should be converted into the lower unit, ie, $s$ or min, respectively. The unit chosen for expressing consecutive data in a series should, if possible, avoid the use of fractions, provided that the numerical value does not exceed 999 (except for years). Thus, for example: $21.5 \mathrm{~min}$ not $1290 \mathrm{~s} ; 50 \mathrm{~ms}$ not $0.05 \mathrm{~s} ; 84 \mathrm{~s}$ rather than $1.4 \mathrm{~min}$ or $1 \mathrm{~min} 24 \mathrm{~s}$; but either $16 \mathrm{~min}$ or $960 \mathrm{~s}$, depending on whether the consecutive data for the series are expressed in minutes or seconds.

The SI symbol for 'day', ie, 24 hours, is ' $d$ ', but urine and faecal excretions of substances should preferably be expressed as 'per 24 hours', eg, g/24 h. Expression as 'per day', eg, g/d, could be interpreted as meaning 'between the hours of sunrise and sunset'.

\section{MEDICAL PHYSICS}

It is recommended that SI units be adopted throughout medical physics, with the temporary exception of the units of radiation dose and radioactivity. The existing special units in these fields (rad, röntgen, rem, curie) are not coherent but have been approved by the General Conference of Weights and Measures for continued use 'for the time being'. Changes in the radiation units are normally recommended by the International Commission on Radiation Units and Measurements and are implemented internationally. This matter is currently under discussion.

\section{IMPLEMENTATION}

SI units have already been introduced into some hospitals and laboratories and it will not be practical to advocate that all laboratories in all hospitals should change on the same date. The Appendix to this paper lists the units which are recommended for measurements which are frequently made in hospital haematology and biochemistry laboratories. The list is not exhaustive but the examples and general principles outlined here should enable an appropriate unit for less common analyses to be chosen 
where necessary. No recommendations are made for the units to be used for measurements of enzyme activity. Whenever a new test is introduced into a hospital, every effort should be made to ensure that the appropriate SI unit is used from the start. In some cases, the selection of the best submultiple, eg, $\mu \mathrm{mol} / 1$ or $\mathrm{nmol} / 1$, can be difficult and alternatives may be equally valid under SI rules. Nevertheless, it is hoped that the subunits listed in the Appendix will be accepted by laboratories in Britain so that there will be conformity throughout the country. The Appendix also lists the ranges of numerical values which will be encountered in practice in both the new and old units, together with conversion factors. However, the conversion factors will depend on the methods and conventions used at present, and since these may vary, they should be carefully checked locally and, where necessary, amended for use within the hospital.

It should be noted that for some tests the numerical value in the new units is the same as that in the current units, but the symbols change, eg, blood platelets $=150000 / \mathrm{mm}^{3}=150 \times 10^{9} / 1$.

It is hoped that the majority of hospital laboratories will have completed the changes, outlined in this paper, by early 1975 . The full implications of the change should be carefully worked out locally; stationery for example may need reprinting, new normal ranges publicized, or tables of conversion factors provided. Individual laboratories may also consider whether all or some results should, for a time, be reported in both new and old units. However, the experience of those who have changed suggests that the transition period within a hospital should be as short as possible.

\section{References}

Anderson, S. G. et al (1972). Measurements of concentrations of human serum immunoglobulins. J. clin. Path., 25, 133-134.

Astrup, P. (1970). The need for a standardization of quantities and units in clinical chemistry (Ed.). Scand. J. clin. Invest., 25, 1-3.

Baron, D. N. (1973). SI units in pathology: the next stage. J. clin. Path., 26, 729-730.

British National Committee for Nutritional Sciences (1972). Metric units, conversion factors and nomenclature in nutritional and food sciences. Royal Society, London.
British Standards Institution (1972). The Use of SI Units, Revised edition. PD 5686. British Standards Institution, London.

ICSH-IFCC-WAPS (1972). Recommendations for the use of SI in clinical laboratory measurements. International Committee for Standardization in Haematology, International Federation of Clinical Chemistry and the World Association of (Anatomic and Clinical) Pathology Societies. Brit.J. Haemat., 23, 787-788.

IUPAC-IFCC (1972a). Information Bulletin No. 20. Appendices on tentative nomenclature, symbols, units and standards. Quantities and units in clinical chemistry. International Union of Pure and Applied Chemistry and International Federation of Clinical Chemistry. Oxford.

IUPAC-IFCC (1972b). Information Bulletin No. 21. Appendices on tentative nomenclature, symbols, units and standards. List of quantities and units in clinical chemistry. Internationa Union of Pure and Applied Chemistry and International Federation of Clinical Chemistry. Oxford.

Owen, J. A., Edwards, R. G., and Collier, B. A W. (1970). The Mole in Medicine and Biology. Livingstone, Edinburgh and London.

Royal College of Pathologists Working Party (1970). The use of Si in reporting results in pathology. J. clin. Path., 23, 818-819.

Royal Society of Medicine (1972). Units, Symbols and Abbreviations: A Guide for Biological and Medical Editors and Authors. Royal Society of Medicine, London.

Young, D. S. (1974). Standardized reporting of laboratory data: the desirability of using SI units. New Engl. J. Med., 290, 368-373.

\section{Appendix}

Table IV lists the recommended units for a range of common biochemical and haematological tests, together with the factors for converting values in the present commonly used units to those in the new units. Molecular and atomic weights of components are also listed to facilitate checking of conversion factors. Approximate normal ranges or typical normal values, together with those likely to be encountered in hospital patients, are quoted to illustrate the magnitude of values, in both new and current units, but it must be remembered that there may be local variations in the exact normal range. For some measurements, the normal range varies with race, age and sex and many show diurnal variations.

For each test, the system is indicated by a symbol: $\mathrm{B}=$ Blood, $\mathrm{CSF}=$ Cerebrospinal fluid, $\mathrm{F}=$ Faeces, $\mathbf{P}=$ Plasma, $\mathbf{S}=$ Serum, $\mathbf{U}=$ Urine. 


\begin{tabular}{|c|c|c|c|c|c|c|}
\hline \multirow[t]{2}{*}{$\begin{array}{l}\text { के } \\
\text { है }\end{array}$} & \multirow[t]{2}{*}{ Components } & \multirow[t]{2}{*}{$\begin{array}{l}\text { Molecular } \\
\text { Weight or } \\
\text { Atomic } \\
\text { Weight }\end{array}$} & \multicolumn{2}{|c|}{$\begin{array}{l}\text { Approximate Normal Ranges or Typical Normal } \\
\text { Values (in parentheses approximate ranges found in } \\
\text { hospital practice) }\end{array}$} & \multirow{2}{*}{$\begin{array}{l}\text { Multiplication Factor } \\
\text { for Exact Conversion } \\
\text { from Present Com- } \\
\text { monly Used Units to } \\
\text { New Units }\end{array}$} & \multirow{2}{*}{ Notes } \\
\hline & & & $\begin{array}{l}\text { Convention in } \\
\text { Current Use }\end{array}$ & $\begin{array}{l}\text { Recommended } \\
\text { Convention }\end{array}$ & & \\
\hline $\mathbf{P}$ & $\begin{array}{l}\text { Amino acid } \\
\text { nitrogen }\end{array}$ & $14 \cdot 01$ & $\begin{array}{l}3 \cdot 5-5 \cdot 5 \mathrm{mg} / 100 \mathrm{ml} \\
(3-30)\end{array}$ & $\begin{array}{l}2 \cdot 5-4 \cdot 0 \mathrm{mmol} / 1 \\
(2-20)\end{array}$ & 0.714 & \\
\hline $\mathbf{U}$ & $\begin{array}{l}\text { Amino acid } \\
\text { nitrogen }\end{array}$ & $14 \cdot 01$ & $\begin{array}{l}50-300 \mathrm{mg} / 24 \mathrm{~h} \\
(50-1000)\end{array}$ & $\begin{array}{l}\text { 4-20 mmol/24h } \\
(4-70)\end{array}$ & 0.0714 & \\
\hline $\mathbf{U}$ & 8-Aminolaevulate & $131 \cdot 1$ & $0 \cdot 1-6 \mathrm{mg} / 24 \mathrm{~h}$ & $0.8-46 \mu \mathrm{mol} / 24 \mathrm{~h}$ & $7 \cdot 63$ & \\
\hline B & Ammonium nitrogen & $14 \cdot 01$ & $\begin{array}{l}40-80 \mu \mathrm{g} / 100 \mathrm{ml} \\
(40-300)\end{array}$ & $\begin{array}{l}24-48 \mu \mathrm{mol} / 1 \\
(24-180)\end{array}$ & 0.714 & \\
\hline B & Ascorbate & $176 \cdot 1$ & $\begin{array}{l}0.8-1.4 \mathrm{mg} / 100 \mathrm{ml} \\
(0 \cdot 1-2 \cdot 0)\end{array}$ & $\begin{array}{l}45-80 \mu \mathrm{mol} / 1 \\
(6-120)\end{array}$ & $56 \cdot 8$ & \\
\hline $\mathbf{U}$ & Ascorbate & $176 \cdot 1$ & $\begin{array}{l}20-50 \mathrm{mg} / 24 \mathrm{~h} \\
(5-100)\end{array}$ & $\begin{array}{l}110-280 \mu \mathrm{mol} / 24 \mathrm{~h} \\
(28-570)\end{array}$ & 5.68 & \\
\hline B & Base excess & - & $\pm 2 \mathrm{mEq} / 1$ & $\pm 2 \mathrm{mmol} / 1$ & No change & \\
\hline $\mathbf{P}$ & Bicarbonate & - & 24-32 mEq/1 & 24-32 $\mathrm{mmol} / \mathrm{l}$ & No change & \\
\hline $\mathbf{P}$ & Bilirubin (total) & $584 \cdot 7$ & $\begin{array}{l}0 \cdot 3-1 \cdot 0 \mathrm{mg} / 100 \mathrm{ml} \\
(0 \cdot 3-30)\end{array}$ & $\begin{array}{l}5-17 \mu \mathrm{mol} / 1 \\
(5-500)\end{array}$ & $17 \cdot 1$ & (a) \\
\hline $\mathbf{S}$ & Caeruloplasmin & 一 & $\begin{array}{l}30-60 \mathrm{mg} / 100 \mathrm{ml} \\
(2-60)\end{array}$ & $\begin{array}{l}300-600 \mathrm{mg} / 1 \\
(20-600)\end{array}$ & 10 & \\
\hline $\mathbf{P}$ & Calcium (total) & $40 \cdot 08$ & $\begin{array}{l}8 \cdot 5-10 \cdot 5 \mathrm{mg} / 100 \mathrm{ml} \\
(4-16)\end{array}$ & $\begin{array}{l}2 \cdot 1-2 \cdot 6 \mathrm{mmol} / 1 \\
(1-4)\end{array}$ & 0.250 & \\
\hline $\mathbf{U}$ & Calcium & 40.08 & $\begin{array}{l}100-300 \mathrm{mg} / 24 \mathrm{~h} \\
(10-500)\end{array}$ & $\begin{array}{l}2 \cdot 5-7 \cdot 5 \mathrm{mmol} / 24 \mathrm{~h} \\
(0 \cdot 2-12)\end{array}$ & 0.0250 & \\
\hline B & $\begin{array}{l}\text { Carbon dioxide } \\
\left(\mathrm{P}_{\mathrm{co}}\right)\end{array}$ & - & $\begin{array}{l}34-46 \mathrm{mmHg} \\
(10-100)\end{array}$ & $\begin{array}{l}4 \cdot 5-6 \cdot 1 \mathrm{kPa} \\
(1 \cdot 3-13)\end{array}$ & 0.133 & \\
\hline $\mathbf{P}$ & $\beta$-carotene & 536.9 & $\begin{array}{l}50-300 \mu \mathrm{g} / 100 \mathrm{ml} \\
(20-500)\end{array}$ & $\begin{array}{l}0.9-5 \cdot 6 \mu \mathrm{mol} / 1 \\
(0 \cdot 4-9)\end{array}$ & 0.0186 & \\
\hline $\mathbf{U}$ & $\begin{array}{l}\text { Catecholamines } \\
\text { (as adrenalin) }\end{array}$ & $183 \cdot 2$ & $\begin{array}{l}10-100 \mu \mathrm{g} / 24 \mathrm{~h} \\
(10-1000)\end{array}$ & $\begin{array}{l}0.05-0.55 \mu \mathrm{mol} / 24 \mathrm{~h} \\
(0.05-5 \cdot 5)\end{array}$ & 0.00546 & \\
\hline $\mathbf{P}$ & Chloride & - & 95-105 mEq/1 & $95-105 \mathrm{mmol} / 1$ & No change & \\
\hline $\mathbf{P}$ & Cholesterol & $386 \cdot 7$ & $\begin{array}{l}140-300 \mathrm{mg} / 100 \mathrm{ml} \\
(100-800)\end{array}$ & $\begin{array}{l}3 \cdot 6-7 \cdot 8 \mathrm{mmol} / 1 \\
(2 \cdot 5-20)\end{array}$ & 0.0259 & (b) \\
\hline $\mathbf{P}$ & Copper & $63 \cdot 54$ & $\begin{array}{l}80-150 \mu \mathrm{g} / 100 \mathrm{ml} \\
(20-200)\end{array}$ & $\begin{array}{l}13-24 \mu \mathrm{mol} / 1 \\
(3 \cdot 0-30)\end{array}$ & $0 \cdot 157$ & \\
\hline $\mathbf{U}$ & Copper & $63 \cdot 54$ & $\begin{array}{l}10-50 \mu \mathrm{g} / 24 \mathrm{~h} \\
(10-500)\end{array}$ & $\begin{array}{l}0.2-0.8 \mu \mathrm{mol} / 24 \mathrm{~h} \\
(0 \cdot 2-8 \cdot 0)\end{array}$ & 0.0157 & \\
\hline $\mathbf{U}$ & Coproporphyrins & 655 & $\begin{array}{l}100-200 \mu \mathrm{g} / 24 \mathrm{~h} \\
(100-1000)\end{array}$ & $\begin{array}{l}0 \cdot 15-0 \cdot 31 \mu \mathrm{mol} / 24 \mathrm{~h} \\
(0 \cdot 2-1 \cdot 5)\end{array}$ & 0.00153 & \\
\hline $\mathbf{P}$ & Cortisol & $362 \cdot 5$ & $\begin{array}{l}10-25 \mu \mathrm{g} / 100 \mathrm{ml} \\
(5-50)\end{array}$ & $\begin{array}{l}280-700 \mathrm{nmol} / \mathrm{l} \\
(140-1400)\end{array}$ & $27 \cdot 6$ & \\
\hline $\mathbf{U}$ & Creatine & $131 \cdot 1$ & $\begin{array}{l}0-50 \mathrm{mg} / 24 \mathrm{~h} \\
(0-250)\end{array}$ & $\begin{array}{l}0-400 \mu \mathrm{mol} / 24 \mathrm{~h} \\
(0-2000)\end{array}$ & $7 \cdot 63$ & \\
\hline $\mathbf{P}$ & Creatinine & $113 \cdot 1$ & $\begin{array}{l}0.7-1.4 \mathrm{mg} / 100 \mathrm{ml} \\
(0.7-15)\end{array}$ & $\begin{array}{l}60-120 \mu \mathrm{mol} / \mathrm{I} \\
(60-1300)\end{array}$ & $88 \cdot 4$ & \\
\hline $\mathbf{U}$ & Creatinine & $113 \cdot 1$ & $\begin{array}{l}1 \cdot 0-2 \cdot 0 \mathrm{~g} / 24 \mathrm{~h} \\
(0 \cdot 2-2)\end{array}$ & $\begin{array}{l}9.17 \mathrm{mmol} / 24 \mathrm{~h} \\
(1 \cdot 7-17)\end{array}$ & $8 \cdot 84$ & \\
\hline $\mathbf{F}$ & $\begin{array}{l}\text { Fat } \\
\text { (as stearic acid) }\end{array}$ & 284 & $\begin{array}{l}3-5 g / 24 h \\
(3-30)\end{array}$ & $\begin{array}{l}11-18 \mathrm{mmol} / 24 \mathrm{~h} \\
(10-100)\end{array}$ & 3.52 & \\
\hline $\mathbf{P}$ & Fibrinogen & - & $\begin{array}{l}150-400 \mathrm{mg} / 100 \mathrm{ml} \\
(50-1000)\end{array}$ & $\begin{array}{l}1 \cdot 5-4 \cdot 0 \mathrm{~g} / 1 \\
(0 \cdot 5-10 \cdot 0)\end{array}$ & 0.01 & \\
\hline $\mathbf{s}$ & Folate & 一 & $\begin{array}{l}3-20 \mathrm{ng} / \mathrm{ml} \\
\text { or } \mu \mathrm{mg} / \mathrm{ml} \\
(0 \cdot 5-25)\end{array}$ & $\begin{array}{l}3-20 \mu \mathrm{g} / 1 \\
(0 \cdot 5-25)\end{array}$ & No change & \\
\hline $\mathbf{U}$ & Formiminoglutamate & $173 \cdot 2$ & $\begin{array}{l}0-30 \mathrm{mg} / 24 \mathrm{~h} \\
(0-500)\end{array}$ & $\begin{array}{l}0-170 \mu \mathrm{mol} / 24 \mathrm{~h} \\
(0-3000)\end{array}$ & $5 \cdot 77$ & \\
\hline B & Glucose & $180 \cdot 2$ & $\begin{array}{l}55-90 \mathrm{mg} / 100 \mathrm{ml} \\
(10-1000)\end{array}$ & $\begin{array}{l}3 \cdot 0-5 \cdot 0 \mathrm{mmol} / 1 \\
(0 \cdot 6-60)\end{array}$ & 0.0555 & \\
\hline $\mathbf{U}$ & Glucose & $180 \cdot 2$ & $\begin{array}{l}0-0.2 \mathrm{~g} / 100 \mathrm{ml} \\
(0-3 \cdot 0)\end{array}$ & $\begin{array}{l}0-11 \mathrm{mmol} / 1 \\
(0-160)\end{array}$ & $55 \cdot 5$ & \\
\hline
\end{tabular}

Table IV Recommended units for some biochemical and haematological tests

(a) Conjugated bilirubin is expressed as bilirubin.

(b) cholesterol esters are expressed as cholesterol. 


\begin{tabular}{|c|c|c|c|c|c|c|}
\hline \multirow[t]{2}{*}{ के } & \multirow[t]{2}{*}{ Components } & \multirow{2}{*}{$\begin{array}{l}\text { Molecular } \\
\text { Weight or } \\
\text { Atomic } \\
\text { Weight }\end{array}$} & \multicolumn{2}{|c|}{$\begin{array}{l}\text { Approximate Normal Ranges or Typical Normal } \\
\text { Values (in parentheses approximate ranges found in } \\
\text { hospital practice) }\end{array}$} & \multirow{2}{*}{$\begin{array}{l}\text { Multiplication Factor } \\
\text { for Exact Conversion } \\
\text { from Present Com- } \\
\text { monly Used Units to } \\
\text { New Units }\end{array}$} & \multirow{2}{*}{ Notes } \\
\hline & & & $\begin{array}{l}\text { Convention in } \\
\text { Current Use }\end{array}$ & $\begin{array}{l}\text { Recommended } \\
\text { Convention }\end{array}$ & & \\
\hline B & Haemoglobin & - & $\begin{array}{l}14.4 \mathrm{~g} / 100 \mathrm{ml} \\
\text { or } \mathrm{g} \%\end{array}$ & $14.4 \mathrm{~g} / \mathrm{dl}$ & No change & (c) \\
\hline $\mathbf{S}$ & Haptoglobins (Hb binding) & - & $30-200 \mathrm{mg} / 100 \mathrm{ml}$ & $0 \cdot 3-2 \cdot 0 \mathrm{~g} / 1$ & 0.01 & \\
\hline $\mathbf{U}$ & $\begin{array}{l}\text { 5-Hydroxyindole } \\
\text { acetate ( } 5 \text { HIAA) }\end{array}$ & $191 \cdot 2$ & $\begin{array}{l}3-14 \mathrm{mg} / 24 \mathrm{~h} \\
(3-50)\end{array}$ & $\begin{array}{l}15-75 \mu \mathrm{mol} / 24 \mathrm{~h} \\
(15-260)\end{array}$ & $5 \cdot 23$ & \\
\hline $\mathbf{U}$ & $\begin{array}{l}\text { 4-Hydroxy } \\
\text { 3-methoxy } \\
\text { mandelate (HMMA) }\end{array}$ & $198 \cdot 2$ & $\begin{array}{l}2-7 \mathrm{mg} / 24 \mathrm{~h} \\
(2-40)\end{array}$ & $\begin{array}{l}10-35 \mu \mathrm{mol} / 24 \mathrm{~h} \\
(10-200)\end{array}$ & 5.05 & \\
\hline $\mathbf{U}$ & Hydroxyproline & $131 \cdot 1$ & $10-35 \mathrm{mg} / 24 \mathrm{~h}$ & $0.08-0.25 \mathrm{mmol} / 24 \mathrm{~h}$ & 0.00763 & \\
\hline $\mathbf{S}$ & Iron & 55.85 & $\begin{array}{l}70-180 \mu \mathrm{g} / 100 \mathrm{ml} \\
(20-400)\end{array}$ & $\begin{array}{l}13-32 \mu \mathrm{mol} / 1 \\
(3 \cdot 6-70)\end{array}$ & 0.179 & \\
\hline $\mathbf{S}$ & $\begin{array}{l}\text { Total iron } \\
\text { binding capacity (as iron) }\end{array}$ & $55 \cdot 85$ & $\begin{array}{l}250-400 \mu \mathrm{g} / 100 \mathrm{ml} \\
(50-500)\end{array}$ & $\begin{array}{l}45-70 \mu \mathrm{mol} / 1 \\
(9-90)\end{array}$ & $0 \cdot 179$ & \\
\hline B & $\begin{array}{l}\text { Ketones } \\
\text { (as acetoacetate) }\end{array}$ & $102 \cdot 1$ & $\begin{array}{l}0 \cdot 8-1 \cdot 4 \mathrm{mg} / 100 \mathrm{ml} \\
(0 \cdot 8-10)\end{array}$ & $\begin{array}{l}80-140 \mu \mathrm{mol} / 1 \\
(80-1000)\end{array}$ & $97 \cdot 9$ & \\
\hline B & Lactate & $90 \cdot 08$ & $\begin{array}{l}3 \cdot 6-13 \cdot 0 \mathrm{mg} / 100 \mathrm{ml} \\
(3-50)\end{array}$ & $\begin{array}{l}0 \cdot 4-1 \cdot 4 \mathrm{mmol} / 1 \\
(0 \cdot 3-5 \cdot 5)\end{array}$ & $0 \cdot 111$ & \\
\hline B & Lead & $207 \cdot 2$ & $\begin{array}{l}10-40 \mu \mathrm{g} / 100 \mathrm{ml} \\
(10-200)\end{array}$ & $\begin{array}{l}0 \cdot 5-2 \cdot 0 \mu \mathrm{mol} / 1 \\
(0 \cdot 5-10)\end{array}$ & 0.0483 & \\
\hline $\mathbf{U}$ & Lead & $207 \cdot 2$ & $\begin{array}{l}30-80 \mu \mathrm{g} / 24 \mathrm{~h} \\
(30-500)\end{array}$ & $\begin{array}{l}0 \cdot 14-0 \cdot 40 \mu \mathrm{mol} / 24 \mathrm{~h} \\
(0 \cdot 14-2 \cdot 5)\end{array}$ & 0.00483 & \\
\hline B & $\begin{array}{l}\text { Leucocytes } \\
\text { (total) (WBC) }\end{array}$ & - & $\begin{array}{l}4000-11000 / \mu 1 \\
\text { or } 4.0-11.0 \times 10^{3} / \mathrm{mm}^{3}\end{array}$ & $4.0-11.0 \times 10^{9} / 1$ & $10^{8}$ & \\
\hline $\mathbf{P}$ & Lipids (total) & $\cdots$ & $\begin{array}{l}400-1000 \mathrm{mg} / 100 \mathrm{ml} \\
(200-2000)\end{array}$ & $\begin{array}{l}4 \cdot 0-10 \cdot 0 \mathrm{~g} / 1 \\
(2 \cdot 0-20)\end{array}$ & 0.01 & \\
\hline $\mathbf{P}$ & Magnesium & $24 \cdot 31$ & $\begin{array}{l}1 \cdot 8-2 \cdot 4 \mathrm{mg} / 100 \mathrm{ml} \\
(1 \cdot 0-5 \cdot 0)\end{array}$ & $\begin{array}{l}0 \cdot 7-1 \cdot 0 \mathrm{mmol} / 1 \\
(0 \cdot 4-2 \cdot 0)\end{array}$ & 0.411 & \\
\hline $\mathbf{U}$ & Magnesium & $24 \cdot 31$ & $\begin{array}{l}80-120 \mathrm{mg} / 24 \mathrm{~h} \\
(5-300)\end{array}$ & $\begin{array}{l}3 \cdot 3-5 \cdot 0 \mathrm{mmol} / 24 \mathrm{~h} \\
(0 \cdot 2-12)\end{array}$ & 0.0411 & \\
\hline B & $\begin{array}{l}\text { Mean cell } \\
\text { haemoglobin } \\
(\mathrm{MCH})\end{array}$ & - & $\begin{array}{l}27-32 \mathrm{pg} \\
\quad \text { or } \mu \mu \mathrm{g}\end{array}$ & $27-32 \mathrm{pg}$ & No change & \\
\hline $\mathbf{B}$ & $\begin{array}{l}\text { Mean cell haemoglobin } \\
\text { concentration (MCHC) }\end{array}$ & - & $30-35 \%$ & $30-35 \mathrm{~g} / \mathrm{dl}$ & No change & \\
\hline B & $\begin{array}{l}\text { Mean cell } \\
\text { volume (MCV) }\end{array}$ & - & $\begin{array}{l}75-95 \mu^{3} \\
\quad \text { or } \mu \mathrm{m}^{3}\end{array}$ & $75-95 \mathrm{fl}$ & No change & \\
\hline $\mathbf{F}$ & Nitrogen & $14 \cdot 01$ & $\begin{array}{l}1-2 \mathrm{~g} / 24 \mathrm{~h} \\
(1-5)\end{array}$ & $\begin{array}{l}70-140 \mathrm{mmol} / 24 \mathrm{~h} \\
(70-360)\end{array}$ & $71 \cdot 4$ & \\
\hline $\mathbf{P}$ & $\begin{array}{l}\text { Non-protein } \\
\text { nitrogen }\end{array}$ & $14 \cdot 01$ & $\begin{array}{l}20-30 \mathrm{mg} / 100 \mathrm{ml} \\
(10-200)\end{array}$ & $\begin{array}{l}14-21 \mathrm{mmol} / \mathrm{l} \\
(7-140)\end{array}$ & 0.714 & \\
\hline $\mathbf{U}$ & Oestriol & $288 \cdot 4$ & $(2-50) \mathrm{mg} / 24 \mathrm{~h}$ & $(7-170) \mu \mathrm{mol} / 24 \mathrm{~h}$ & $3 \cdot 47$ & \\
\hline $\mathbf{P}$ & Osmolality & - & $275-295 \mathrm{mosmol} / \mathrm{kg}$ & $275-295 \mathrm{mmol} / \mathrm{kg}$ & No change & \\
\hline $\mathbf{U}$ & Oxalate & 90.04 & $\begin{array}{l}20-40 \mathrm{mg} / 24 \mathrm{~h} \\
(20-150)\end{array}$ & $\begin{array}{l}0 \cdot 2-0 \cdot 4 \mathrm{mmol} / 24 \mathrm{~h} \\
(0 \cdot 2-1 \cdot 7)\end{array}$ & 0.0111 & \\
\hline B & Oxygen $\left(\mathrm{Po}_{2}\right)$ & - & $\begin{array}{l}90-110 \mathrm{mmHg} \\
(20-400)\end{array}$ & $\begin{array}{l}12-15 \mathrm{kPa} \\
(2 \cdot 5-50)\end{array}$ & $0 \cdot 133$ & \\
\hline $\mathbf{U}$ & $\begin{array}{l}17 \text { Oxogenic steroids (as } \\
\text { dehydro-epiandrosterone) }\end{array}$ & $288 \cdot 4$ & $\begin{array}{l}10-20 \mathrm{mg} / 24 \mathrm{~h} \\
(2-50)\end{array}$ & $\begin{array}{l}35-70 \mu \mathrm{mol} / 24 \mathrm{~h} \\
(70-170)\end{array}$ & $3 \cdot 47$ & \\
\hline $\mathbf{U}$ & $\begin{array}{l}\text { 17-Oxosteroids (as } \\
\text { dehydro-epiandrosterone) }\end{array}$ & $288 \cdot 4$ & $\begin{array}{l}10-25 \mathrm{mg} / 24 \mathrm{~h} \\
(2-50)\end{array}$ & $\begin{array}{l}35-85 \mu \mathrm{mol} / 24 \mathrm{~h} \\
(7 \cdot 0-170)\end{array}$ & 3.47 & \\
\hline B & Packed cell volume (PCV) & - & $41 \%$ & $0 \cdot 41$ & 0.01 & $(c, d)$ \\
\hline B & Platelets & - & $\begin{array}{r}150000-400000 / \mu 1 \\
\text { or } / \mathrm{mm}^{3}\end{array}$ & $150-400 \times 10^{9} / 1$ & $10^{8}$ & \\
\hline $\mathbf{P}$ & Phenylalanine & $165 \cdot 2$ & $\begin{array}{l}1 \cdot 0-3 \cdot 0 \mathrm{mg} / 100 \mathrm{ml} \\
(1 \cdot 0-50)\end{array}$ & $\begin{array}{l}0.06-0.2 \mathrm{mmol} / 1 \\
(0.06-3 \cdot 0)\end{array}$ & 0.0605 & \\
\hline $\mathbf{P}$ & Phospholipid-phosphorus & $30 \cdot 97$ & $\begin{array}{l}5-10 \mathrm{mg} / 100 \mathrm{ml} \\
(5-30)\end{array}$ & $\begin{array}{l}1 \cdot 6-3 \cdot 2 \mathrm{mmol} / \mathrm{l} \\
(1 \cdot 6-10)\end{array}$ & 0.323 & \\
\hline
\end{tabular}

Table IV (cont)

(c) normal ranges for these substances are not given, as these depend on sex.

(d) no unit is necessary but $1 / 1$ is implied. 


\begin{tabular}{|c|c|c|c|c|c|c|}
\hline \multirow[t]{2}{*}{$\begin{array}{l}\text { है } \\
\text { के }\end{array}$} & \multirow[t]{2}{*}{ Components } & \multirow{2}{*}{$\begin{array}{l}\text { Molecular } \\
\text { Weight or } \\
\text { Atomic } \\
\text { Weight }\end{array}$} & \multicolumn{2}{|c|}{$\begin{array}{l}\text { Approximate Normal Ranges or Typical Normal } \\
\text { Values (in parentheses approximate ranges found in } \\
\text { hospital practice) }\end{array}$} & \multirow{2}{*}{$\begin{array}{l}\text { Multiplication Factor } \\
\text { for Exact Conversion } \\
\text { from Present Com- } \\
\text { monly Used Units to } \\
\text { New Units }\end{array}$} & \multirow{2}{*}{ Notes } \\
\hline & & & $\begin{array}{l}\text { Convention in } \\
\text { Current Use }\end{array}$ & $\begin{array}{l}\text { Recommended } \\
\text { Convention }\end{array}$ & & \\
\hline $\mathbf{P}$ & $\begin{array}{l}\text { Phosphate } \\
\text { (as inorganic P) }\end{array}$ & $30 \cdot 97$ & $\begin{array}{l}2 \cdot 5-4 \cdot 5 \mathrm{mg} / 100 \mathrm{ml} \\
(1 \cdot 5-10)\end{array}$ & $\begin{array}{l}0 \cdot 8-1 \cdot 4 \mathrm{mmol} / \mathrm{l} \\
(0 \cdot 5-3 \cdot 2)\end{array}$ & 0.323 & \\
\hline $\mathbf{U}$ & $\begin{array}{l}\text { Phosphate } \\
\text { (as inorganic P) }\end{array}$ & 30.97 & $\begin{array}{l}0.5-1 \cdot 5 \mathrm{~g} / 24 \mathrm{~h} \\
(0 \cdot 2-2)\end{array}$ & $\begin{array}{l}15-50 \mathrm{mmol} / 24 \mathrm{~h} \\
(6 \cdot 5-65)\end{array}$ & $32 \cdot 3$ & \\
\hline $\mathbf{U}$ & Porphobilinogen & $226 \cdot 2$ & $\begin{array}{l}0 \cdot 2-2 \mathrm{mg} / 24 \mathrm{~h} \\
(0 \cdot 2-20)\end{array}$ & $\begin{array}{l}1-10 \mu \mathrm{mol} / 24 \mathrm{~h} \\
(1-100)\end{array}$ & 4.42 & \\
\hline $\mathbf{P}$ & Potassium & - & $3.8-5.0 \mathrm{mEq} / 1$ & $3 \cdot 8.5 .0 \mathrm{mmol} / 1$ & No change & \\
\hline $\mathbf{U}$ & Pregnanediol & $320 \cdot 5$ & $\begin{array}{l}0-1 \mathrm{mg} / 24 \mathrm{~h} \\
(0-20)\end{array}$ & $\begin{array}{l}0-3 \cdot 1 \mu \mathrm{mol} / 24 \mathrm{~h} \\
(0-62)\end{array}$ & $3 \cdot 12$ & \\
\hline $\mathbf{U}$ & Pregnanetriol & $336 \cdot 5$ & $\begin{array}{l}0 \cdot 1-3 \mathrm{mg} / 24 \mathrm{~h} \\
(0 \cdot 1-5)\end{array}$ & $\begin{array}{l}0 \cdot 3-9 \cdot 0 \mu \mathrm{mol} / 24 \mathrm{~h} \\
(0 \cdot 3-15)\end{array}$ & $2 \cdot 97$ & \\
\hline $\mathbf{S}$ & Proteins Total & 一 & $\begin{array}{l}6 \cdot 2-8 \cdot 2 \mathrm{~g} / 100 \mathrm{ml} \\
(4-10)\end{array}$ & $\begin{array}{l}62-82 \mathrm{~g} / 1 \\
(40-100)\end{array}$ & $10 \cdot 0$ & \\
\hline $\mathbf{s}$ & Albumin & - & $\begin{array}{l}3 \cdot 6-5 \cdot 2 \mathrm{~g} / 100 \mathrm{ml} \\
(1-5)\end{array}$ & $\begin{array}{l}36-52 \mathrm{~g} / 1 \\
(10-50)\end{array}$ & 10.0 & \\
\hline $\mathbf{s}$ & Globulins & - & $\begin{array}{l}2 \cdot 4-3 \cdot 7 \mathrm{~g} / 100 \mathrm{ml} \\
(2-10)\end{array}$ & $\begin{array}{l}24-37 g / 1 \\
(20-100)\end{array}$ & $10 \cdot 0$ & \\
\hline CSI & Proteins & - & $\begin{array}{l}10-40 \mathrm{mg} / 100 \mathrm{ml} \\
(10-2000)\end{array}$ & $\begin{array}{l}0 \cdot 1-0 \cdot 4 \mathrm{~g} / 1 \\
(0 \cdot 1-20)\end{array}$ & 0.01 & \\
\hline $\mathbf{S}$ & $\begin{array}{l}\text { Protein-bound } \\
\text { iodine }\end{array}$ & 126.9 & $\begin{array}{l}4 \cdot 0-7 \cdot 5 \mu \mathrm{g} / 100 \mathrm{ml} \\
(1-20)\end{array}$ & $\begin{array}{l}300-600 \mathrm{nmol} / 1 \\
(80-1600)\end{array}$ & $78 \cdot 8$ & \\
\hline B & Pyruvate & 88.06 & $\begin{array}{l}0.4-0.7 \mathrm{mg} / 100 \mathrm{ml} \\
(0.4-3.0)\end{array}$ & $\begin{array}{l}45-80 \mu \mathrm{mol} / 1 \\
(50-300)\end{array}$ & $113 \cdot 5$ & \\
\hline B & $\begin{array}{l}\text { Red cell count } \\
\text { (RBC) }\end{array}$ & - & $\begin{array}{c}4.5 \times 10 \% / \mu 1 \\
\text { or } / \mathrm{mm}^{3}\end{array}$ & $4.5 \times 10^{12} / 1$ & $10^{\circ}$ & (c) \\
\hline B & Red cell diametor & - & $\begin{array}{l}6.7-7.7 \mu \\
\quad \text { or } \mu \mathrm{m}\end{array}$ & $6.7-7.7 \mu \mathrm{m}$ & No change & \\
\hline B & Reticulocytes & - & $\begin{array}{l}0.2-2 \cdot 0 \% \\
\text { or } 10-100 \times 10^{3} / \mu 1\end{array}$ & $\begin{array}{l}0.2-2.0 \% \\
\text { or } 10-100 \times 10^{\circ} / 1\end{array}$ & $\begin{array}{l}\text { No change } \\
10^{\circ}\end{array}$ & \\
\hline $\mathbf{P}$ & Sodium & - & $136-148 \mathrm{mEq} / 1$ & $136-148 \mathrm{mmol} / 1$ & No change & \\
\hline $\mathbf{s}$ & Thyroxine-iodine & 126.9 & $\begin{array}{l}3 \cdot 1-5 \cdot 9 \mu \mathrm{g} / 100 \mathrm{ml} \\
(1-20)\end{array}$ & $\begin{array}{l}240-450 \mathrm{nmol} / 1 \\
(80-1600)\end{array}$ & $78 \cdot 8$ & \\
\hline $\mathbf{s}$ & Transferrin & - & $\begin{array}{l}120-200 \mathrm{mg} / 100 \mathrm{ml} \\
(100-500)\end{array}$ & $\begin{array}{l}1 \cdot 2-2 \cdot 0 \mathrm{~g} / 1 \\
(1 \cdot 0-5 \cdot 0)\end{array}$ & 0.01 & \\
\hline $\mathbf{P}$ & $\begin{array}{l}\text { Triglyceride } \\
\text { (as triolein) }\end{array}$ & $885 \cdot 5$ & $\begin{array}{l}25-150 \mathrm{mg} / 100 \mathrm{ml} \\
(25-2000)\end{array}$ & $\begin{array}{l}0.3-1.7 \mathrm{mmol} / 1 \\
(0 \cdot 3-23)\end{array}$ & 0.0113 & \\
\hline $\mathbf{P}$ & Urate & $168 \cdot 1$ & $\begin{array}{l}2-7 \mathrm{mg} / 100 \mathrm{ml} \\
(2-12)\end{array}$ & $\begin{array}{l}0 \cdot 1-0.4 \mathrm{mmol} / \mathrm{l} \\
(0.1-0.7)\end{array}$ & 0.0595 & \\
\hline $\mathbf{U}$ & Urate & $168 \cdot 1$ & $0.5-2.0 \mathrm{~g} / 24 \mathrm{~h}$ & 3-12 mmol/24h & 5.95 & \\
\hline B & Urea & 60.06 & $\begin{array}{l}15-40 \mathrm{mg} / 100 \mathrm{ml} \\
(15-500)\end{array}$ & $\begin{array}{l}2 \cdot 5-6.5 \mathrm{mmol} / 1 \\
(2 \cdot 5-80)\end{array}$ & 0.166 & \\
\hline $\mathbf{U}$ & Urea & 60.06 & $\begin{array}{l}1.5-3.0 \mathrm{~g} / 100 \mathrm{ml} \\
(0.2-4.0)\end{array}$ & $\begin{array}{l}250-500 \mathrm{mmol} / 1 \\
(35-660)\end{array}$ & 166 & \\
\hline $\mathbf{F}$ & Urobilinogen & 596 & $\begin{array}{l}30-300 \mathrm{mg} / 24 \mathrm{~h} \\
(30-1000)\end{array}$ & $\begin{array}{l}50-500 \mu \mathrm{mol} / 24 \mathrm{~h} \\
(50-1700)\end{array}$ & 1.68 & \\
\hline $\mathbf{U}$ & $\begin{array}{l}\text { Uroporphyrins } \\
\text { (I + III) }\end{array}$ & 830 & $\begin{array}{l}0-25 \mu \mathrm{g} / 24 \mathrm{~h} \\
(0-1000)\end{array}$ & $\begin{array}{l}0-30 \mathrm{nmol} / 24 \mathrm{~h} \\
(0-1200)\end{array}$ & $1 \cdot 20$ & \\
\hline $\mathbf{P}$ & Vitamin A & $286 \cdot 4$ & $\begin{array}{l}20-50 \mu \mathrm{g} / 100 \mathrm{ml} \\
(20-500)\end{array}$ & $\begin{array}{l}0.7-1.7 \mu \mathrm{mol} / 1 \\
(0.7-17.4)\end{array}$ & 0.0349 & \\
\hline $\mathbf{S}$ & $\begin{array}{l}\text { Vitamin } \mathbf{B}_{12} \\
\text { (as cyanocobalamin) }\end{array}$ & - & $\begin{array}{l}160-925 \mathrm{pg} / \mathrm{ml} \\
\text { or } \mu \mu \mathrm{g} / \mathrm{ml}\end{array}$ & $160-925 \mathrm{ng} / 1$ & No change & \\
\hline
\end{tabular}

Table IV (cont)

(c) normal ranges for these substances are not given, as these depend on sex. 